\title{
Earthquakes and ghost towns in Sicily: from the Valle del Belìce in 1968 to the Val di Noto in 1693. The first stage of the virtual seismic itinerary through Italy
}

\author{
Raffaele Azzaro*,1, Massimiliano Cascone ${ }^{2}$, Alfio Amantia ${ }^{1}$ \\ (1) Istituto Nazionale di Geofisica e Vulcanologia, Osservatorio Etneo, Catania, Italy \\ (2) Istituto Nazionale di Geofisica e Vulcanologia, Sezione di Pisa, Pisa, Italy
}

Article history: received April 7, 2019; accepted September 5, 2019

\begin{abstract}
Destructive earthquakes leave traces not only on the physical landscape but also on human processes. Among the most devastating consequences is the abandoning of towns and villages, in favour of locations deemed safer. Abandoning a village and resettling in a new location, whether a gradual process or the result of a sudden traumatic situation, is an event of great historical, cultural and anthropological impact. It entails the loss of a piece of history or culture - local identity - and the more suddenly it happens, the more dramatic the after-effects. Italy has almost two hundred localities that have been abandoned for different causes (landslides, floods, volcanic eruptions, but also social or environmental reasons), some ninety of them owing to earthquakes. Sicily, a land of volcanoes and earthquakes, has several traces of former villages either in the form of fairly substantial ruins or even half-destroyed, which are usually located a few kilometres away from the new settlements. In this paper, we present the methodological approach developed in the framework of the EDURISK Project to enhance the awareness of seismic risk as an element of daily life; the case-study of the Valle del Belice after the 1968 earthquakes represents the richness and complexity of this approach well. Following this rationale, in 2006, we published the first multimedia product devoted to Sicily based on the tools available at that time: a DVD-Rom hosting the interactive Quick Time $^{\mathrm{TM}}$ Virtual Reality format. Today, multimedia technology is much more advanced and weboriented, but the methodological approach is still valid.
\end{abstract}

Keywords: Sicily, Ghost towns, Earthquakes.

\section{Introduction}

Destructive earthquakes leave deep scars on the territory, both on the physical landscape (e.g. large landslides) and on society. One of the most striking effects is the abandonment of villages and towns, even important ones, in favor of new ones believed safer with respect to the causative event or also more suitable for the changed socialeconomic conditions [e.g. Camassi, 2004]. Abandoning a town and resettling the community in a new site, whether 


\section{Raffaele Azzaro et al.}

as result of a process over time or of a sudden traumatic situation, is an event of wide historical, cultural and anthropological impact [e.g. Teti, 2004]. Indeed, in many cases it leads to the loss of a piece of local history and culture, especially when the change is rapid.

Abandoned settlements are therefore the most spectacular testimonies to the fragility of the territory. Better than any other evidence, they show the impact of a seismic event on the life of a community. For this reason, their rediscovery is a unique opportunity from a cultural standpoint to enhance the awareness of seismic risk as an element of daily life [Bitelli et al., 2000a]. This rationale has been developed in the framework of the EDURISK Project (Earthquake eDUcation: an investigative journey into seismic RISK reduction, www.edurisk.it), funded since 2002 by the Italian Civil Protection Department [Camassi et al., 2005; Pessina and Camassi, 2012].

One of the main tasks of the project was to prepare a series of virtual journeys through the traces left by past destructive earthquakes in Italy [Azzaro, 2012]. In this paper, we present the first interactive multimedia (DVD) created on a regional scale, devoted to the virtual navigation throughout the seismic itineraries of Sicily [Azzaro et al., 2006]. As a prototype for other earthquake-prone regions, it has been designed as a multidisciplinary tool to document features and effects of the earthquakes, their social impact and reconstruction dynamics; information on the seismic classification is also provided. In the following, the criteria and methodological approach applied in this work are described in detail together with some cultural aspects resulting from the critical reading of the materials.

\section{Deserted settlements in Italy: a brief overview}

A detailed investigation on a wide range of historical sources and recent studies was the first step to obtain a preliminary inventory of abandoned settlements throughout Italy [Camassi, 2004]. As a result, nearly two hundred localities were recognized as having been abandoned for different natural causes including, in order of importance, landslides, floods, earthquakes and volcanic eruptions, but there are also situations determined by long-lasting effects due to environmental and anthropic reasons (Figure 1a). For example, the defensive position of the medieval villages on the top of hills was no longer necessary after the 17th century and new towns were established in better sites for trading and farming [Klapisch-Zuber, 1973]. One clue to such a process is the frequency, in the Italian territory, of place names tagged with "vecchio" or "antico" (old) or "nuovo" (new).

Overall, some ninety settlements were abandoned as a consequence of earthquakes, although in a few cases this was not the sole cause. Traces of the ancient sites are of archaeological type, usually identifiable a few kilometres away from the new towns and visible in the form of more or less evident isolated remains or settlements in ruins (since the late 1800s). Most of them are located in Central and Southern Italy (Figure 1b), namely in regions prone to destructive earthquakes, especially in connection with the great seismic sequences occurring in 1703 in the Central Apennines, 1783 in Calabria and 1693 in Eastern Sicily (Figure 1c). Two very apparent spots of deserted localities appear at the extremities of the peninsula: the first in north-west Italy at the border with France, where the abandonment was caused by the M6.3 1887 earthquake; the second in Western Sicily as a consequence of the 1968 Valle del Belìce earthquakes.

\section{Ghost towns in Sicily: a journey through time}

In Sicily, the case-studies regard very different situations, both from the historical viewpoint of the period concerned and the geo-anthropological features of the affected areas; in all, 17 sites which underwent total or partial resettlement have been identified (Figure 1d). In particular, six ghost towns are related to the "recent" 1968 seismic period in Western Sicily (namely Valle del Belìce) [Gangemi and La Franca, 1979], occurring in an area considered poorly seismic up until this date. The largest group of abandoned settlements (10 sites) is associated with the 1693 earthquakes, one of the main Italian seismic catastrophes that caused extensive destruction in the towns of Eastern Sicily (also known as Val di Noto) [Dufour and Raymond, 1994]. Finally, the case-study presented for North-eastern Sicily is unique since the abandonment is a consequence of the earthquakes devastating Southern Calabria in 1783 [Principe, 2001]. Linking the abandonment to the causative earthquake, we have grouped these ghost towns into three distinct macro-areas, namely the 1693 Val di Noto, 1783 Val Dèmone and 1968 Valle del Belìce (Table 1). 

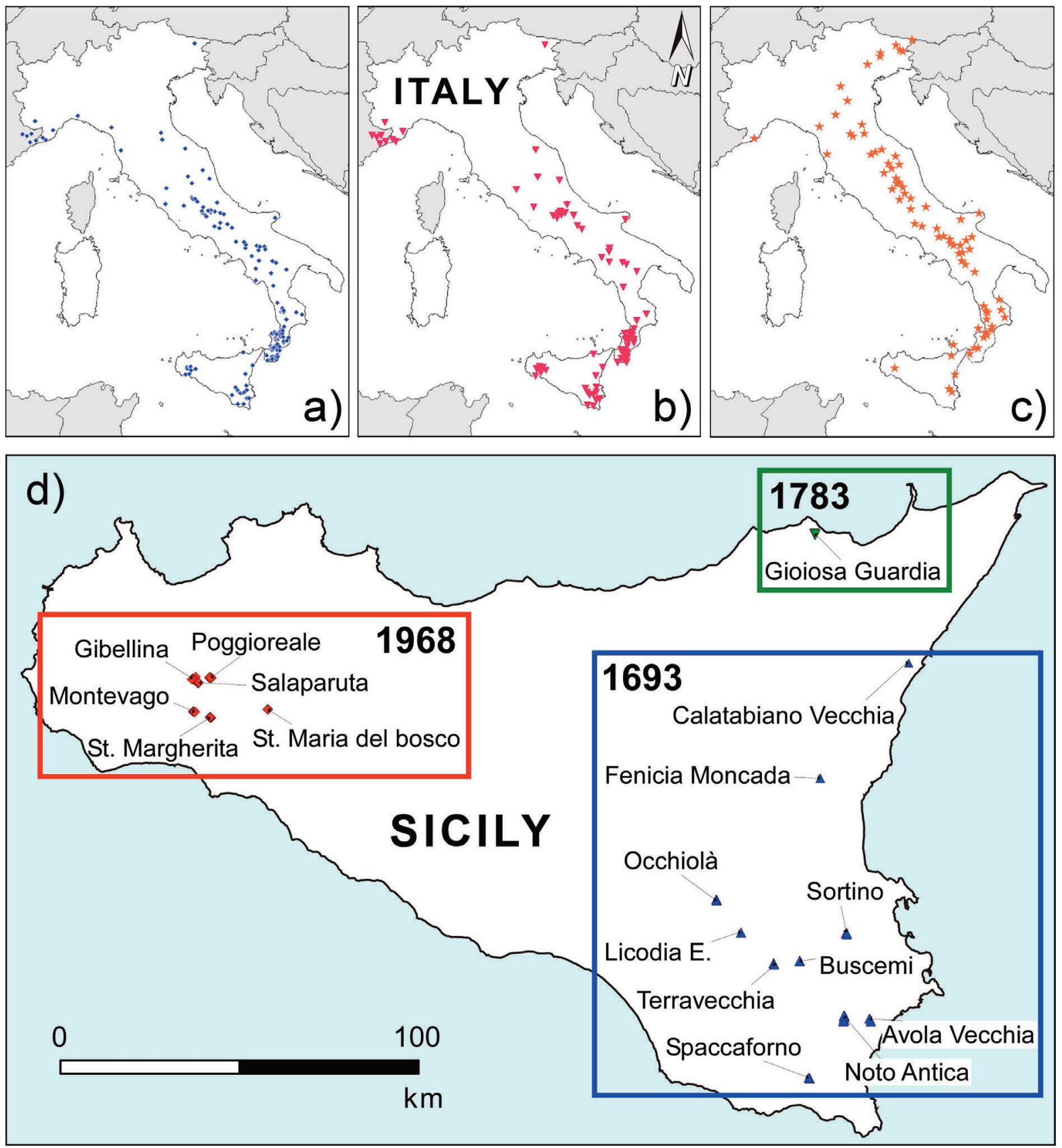

Figure 1. (a) Location of the towns and villages abandoned in Italy as a consequence of natural phenomena and other anthropic causes. (b) Localities deserted following destructive earthquakes. (c) Distribution of $\mathrm{M} \geq 6.0$ earthquakes according to the CPTI15 catalogue [Rovida et al., 2016]. (d) Ghost towns in Sicily; dates refer to the earthquakes responsible for the abandonment of the sites.

In general, the deserted settlements presented here show heterogeneous characteristics also within the same group, firstly with respect to how they appear today. In the Valle del Belice, in only a couple of cases, such as Poggioreale and Santa Margherita, is the field evidence still impressive, while at the other localities the remains are quickly disappearing despite the short time elapsed since 1968. This is largely due to the complete lack of preservation measures to counteract the theft of the few remains and the dismantling action of vegetation. Secondly, there is the different size of the settlements. These range from important towns such as Noto Antica - the old administrative capital of the wealthy Val di Noto from the Arab period till the 1693 earthquakes - to mountain villages, but also a few isolated ruins with a certain relevance from the historical and artistic points of view. 
Raffaele Azzaro et al.

\begin{tabular}{|c|c|c|c|c|c|c|}
\hline $\begin{array}{l}\text { Deserted } \\
\text { locality }\end{array}$ & $\begin{array}{l}\text { Inhabitants } \\
\text { before } \\
\text { abandonment }\end{array}$ & $\begin{array}{l}\text { Coordinates } \\
\text { Lat - Long }\end{array}$ & $\begin{array}{l}\text { Altitude } \\
\text { (m a. s.1.) }\end{array}$ & $\begin{array}{c}\text { Distance } \\
\text { from the } \\
\text { new site (km) }\end{array}$ & $\begin{array}{c}\text { New } \\
\text { settlement }\end{array}$ & District \\
\hline \multicolumn{7}{|l|}{ Val di Noto (1693) } \\
\hline Avola Vecchia & 6000 & $36.9354-15.1085$ & 400 & 4 & Avola & Syracuse \\
\hline Buscemi & 2200 & $37.0834-14.8847$ & 760 & 0,3 & Buscemi & Syracuse \\
\hline Calatabiano Vecchia & 800 & $37.8292-14.9496$ & 210 & 1 & Calatabiano & Catania \\
\hline Fenicia Moncada & 1600 & $37.5408-14.9496$ & 250 & 6 & Belpasso & Catania \\
\hline Licodia & 3000 & $37.1548-14.6993$ & 580 & adjacent & Licodia Eubea & Catania \\
\hline Noto Antica & 12000 & $36.9412-15.0237$ & 409 & 7 & Noto & Syracuse \\
\hline Occhiolà & 3000 & $37.2369-14.6230$ & 480 & 7 & Grammichele & Catania \\
\hline Sortino Vecchia & 6000 & $37.1535-15.0326$ & 380 & 0,5 & Sortino & Syracuse \\
\hline Spaccaforno & 8000 & $36.7908-14.9157$ & 170 & 1 & Ispica & Ragusa \\
\hline Terravecchia & 3000 & $37.0779-14.8025$ & 770 & 3 & Giarratana & Ragusa \\
\hline \multicolumn{7}{|l|}{ Valle del Belìce (1968) } \\
\hline Gibellina & 5800 & $37.7880-12.9743$ & 450 & 10 & Gibellina nuova & Trapani \\
\hline Montevago & 3000 & $37.7072-12.9740$ & 380 & 1 & Montevago nuova & Agrigento \\
\hline Poggioreale & 2700 & $37.7917-13.0270$ & 400 & 7 & Poggioreale nuova & Trapani \\
\hline Salaparuta & 2800 & $37.7789-12.9887$ & 385 & 5 & Salaparuta nuova & Trapani \\
\hline Santa Margherita & 7000 & $37.6928-13.0267$ & 420 & 0,3 & Santa Margherita & Agrigento \\
\hline Santa Maria del Bosco & - & $37.7132-13.2067$ & 827 & abandoned & & Palermo \\
\hline \multicolumn{7}{|l|}{ Val Dèmone (1783) } \\
\hline Gioiosa Guardia & 450 & $38.1512-14.9314$ & 803 & 10 & Gioiosa Marea & Messina \\
\hline
\end{tabular}

Table 1. Inventory of the towns abandoned after earthquakes in Sicily.

Among them, we have documented the Benedictine abbey of Santa Maria del bosco, the Capuchin convent of Buscemi, the stronghold of Spaccaforno, examples of small pearls of the Sicilian cultural heritage exposed to seismic risk.

Finally, special mention should be given to Fenicia Moncada, a settlement located at the extreme southern periphery of the Etna region. This case study represents a perfect example of the ways in which a single community reacted to extreme natural events, such as the $1669 \mathrm{Mt}$. Etna eruption and the 1693 Val di Noto earthquakes [Branca et al., 2015]. After the original village of Malpasso was completely buried by the lava, the new settlement of Fenicia Moncada was built in a position sufficiently far from the volcano to make it unlikely to be affected by future eruptions. Although it was not destroyed by the 1693 earthquakes, the local community decided to transfer the village back again to the slopes of the volcano, not far from the former site (today Belpasso). A rare case of reconstruction repeated three times in less than fifty years, testifying to how a small community seeks to maintain their identity with a particular place, despite its hazardousness.

\section{Documenting abandoned sites: methodological approach}

The second step of our work was to collect different kinds of materials in order to fully document the selected sites. Traces of seismic catastrophes can be found in the local history (when, how), traditions (religious rites), but 
also architecture (construction techniques). Our general guideline was to show abandoned towns as they were before the abandonment compared with the archaeological remains visible today, and to analyse the earthquakes' impact on the community that determined the resettlement in a new site. An approach linking, in practice, the past and present of a community in its own territory.

The macro-areas investigated in Sicily represent highly heterogeneous situations from the view point of documentary data typologies. This mostly depends on the historical period analysed. For example, in the cases of the 1693-1783 earthquakes sources of relevant information include both descriptions by contemporary witnesses and iconographic material of the considered settlements (maps, pictures and paintings), while for the "recent" 1968 Valle del Belice earthquakes there is a rich multi-disciplinary bibliography as well as many photographs and videos (Figure 2).

Finally, the current condition of the abandoned sites has been documented by a detailed photographic survey. Apart from the virtual navigation reported below, the images give a real measure of the severe degradation of the sites even on a ten-year scale, a pertinent reminder of the need to undertake relevant preservation actions; some examples will be shown in chapter 6 . In the following, we briefly describe the typologies of documentary data.
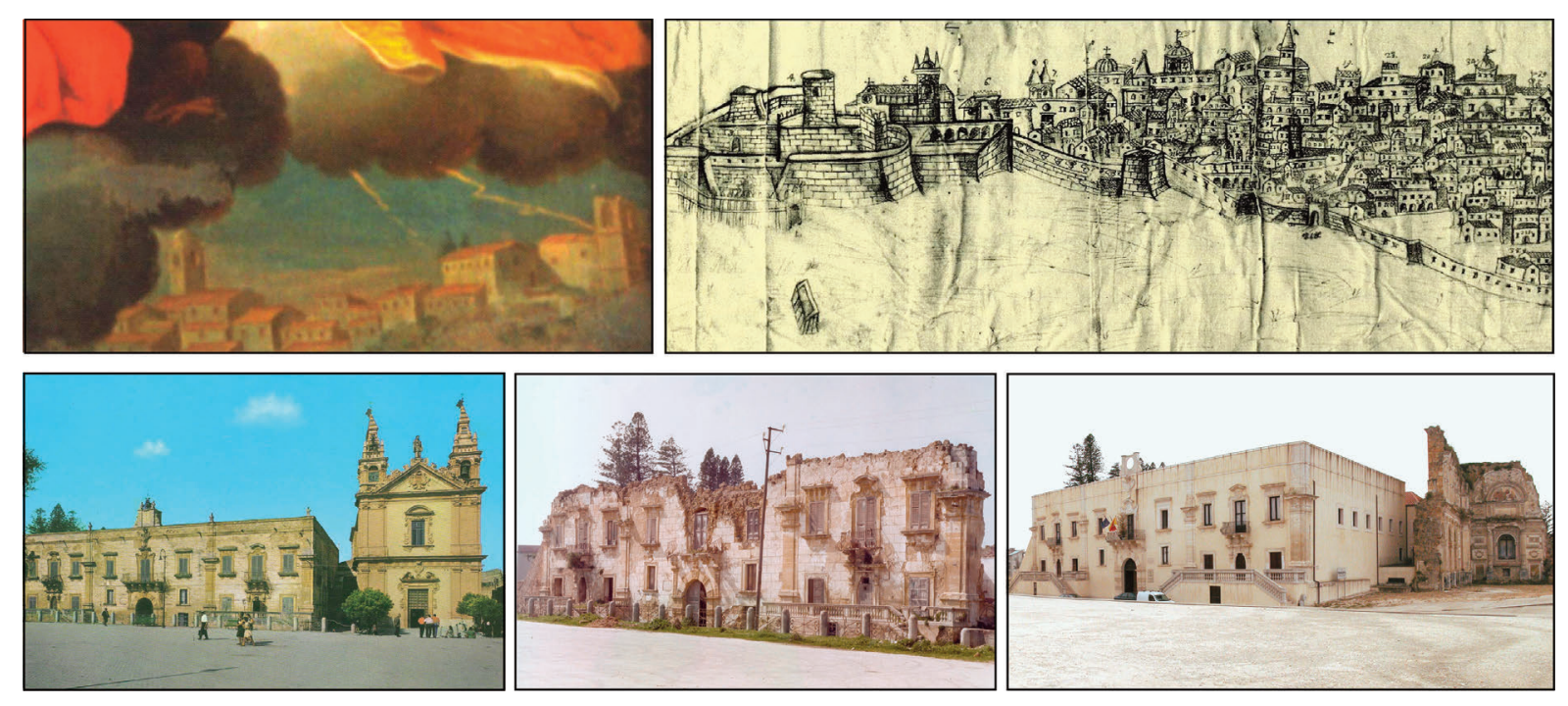

Figure 2. (top) Before the abandonment: painting of Gioiosa Guardia (1783 earthquakes) [Mollica, 2003] and drawing of Noto (1693 earthquakes) [Tobriner, 1982]; (bottom) Santa Margherita, the Palace of the Princes Filangeri di Cutò before and after the 1968 earthquakes (courtesy of R. Taiani), and today after restoration.

\subsection{Historical investigations}

In general, the historical analysis is aimed at (i) reconstructing the history and evolution of the settlements, (ii) making an analysis of the process leading to the abandonment in relation to the social context, (iii) searching for elements of building vulnerability in the concerned territory and, last but not least, (iv) recovering memories and traditions linked to the traumatic events and looking for their positive meaning (life goes on, people find ways to cope with uncertainty, etc.).

Bibliography reporting contemporary accounts on the effects produced by earthquakes is well known to historical seismologists, so we had only to select the sources relevant to a given settlement (see the list reported in the Appendix 1). For the other aspects, it was necessary to consider other kinds of sources and then integrate pieces of useful information to cover the aforementioned aspects.

On the whole, for the case studies of Sicily we examined a bibliography totaling more than one hundred sources of different kinds, from local diaries to socio-anthropological and architectural studies, as well as newspapers (for the 1968 earthquakes). 


\section{Raffaele Azzaro et al.}

\subsection{Photo and video documentation}

Since the late 1800s, photography has represented a powerful means of documentation when dealing with seismic disasters. Some images of devastation entered into collective memory, characterizing each earthquakes by different stereotypes; for example, the ones of the 1908 Messina earthquake focus considerably on the human dimension of the disaster [Azzaro et al., 2008].

The 1968 Valle del Belice case-history, as for other recent earthquakes, is documented by a huge number of photographs coming from books, photographic archives of newspapers - mainly regional such as l'Ora and Giornale di Sicilia printed in Palermo, or La Sicilia in Catania - as well as from private collections. At that time also video shooting was common both by the Italian television and local moviemakers. Therefore, the search sought to document (i) life scenes before and after the abandonment, (ii) damage effects (settlement or single building), (iii) rescue operations and (iv) architectonic and construction features. As a result, we selected some hundred photos and more than 1 hour of film.

On the other hand, we had to document the present condition of all considered sites. To this end, we made a photographic survey throughout the ghost towns in Sicily by using digital technologies for subsequent multimedia processing. The campaign was carried out during the spring and autumn, when the landscape in Sicily features bright colours without the yellowish hue prevailing in the summer season. In all, we collected more than 3100 photos to be used for the virtual navigation (see section 5.1).

\subsection{The multimedia tool}

The last step was to design a multimedia product that linked the navigation throughout the abandoned sites together with the different aspects, both material and immaterial (landscape, construction techniques and architecture, history, folklore and religious beliefs), strictly related to the earthquake. This goal required a highly innovative product at that time, based on the Quick Time ${ }^{\mathrm{TM}}$ Virtual Reality [QTVR, see Kitchens, 1998] to visit virtually the deserted settlements and navigate interactively through the different kinds of documents described above [Bitelli et al., 2000b].

In short, QTVR allows interactive virtual navigation through a scene (the studied site) starting from a set of nodes (shooting points) [Stern and Lettieri, 2002]. Each node consists of a series of images captured around a single point of rotation ( $360^{\circ}$ or less) provided that: (i) the camera rotates on the axis perpendicular to the one of the lens, (ii) the camera is corrected for parallax, and (iii) the lens produces rectilinear images. Images have been acquired by a digital Nikon camera, in JPEG file format at a resolution of 2560 x 1920 pixels, by using two lenses (28 and 35 $\mathrm{mm}$ ) and a special tripod for QTVR shooting.

\section{Results: the DVD-Rom}

In 2003-6, when we were working on the ghost towns in Sicily, the availability of multimedia tools capable of including QTVR navigation and other types of content, with a good resolution and interactively linked, was quite limited. So the choice fell on using the DVD-Rom, which was mounted by the Macromedia Director ${ }^{\mathrm{TM}}$ multimedia authoring environment, a platform created for stand-alone multimedia applications. Looking at the resources available on the internet today, this may appear rather impractical since the distribution of a physical support occurs only by hand and upgrades cannot be performed without a new release of the DVD.

Keeping in mind the educational strategy at the base of the virtual seismic itineraries, we therefore created a multimedia product through which the user - high school students as well as adults - can navigate through space and time, visit the ghost towns, reconstruct the historical events leading to the abandonment and consider the earthquake as an element of fragility of their own territory. In order to disseminate the DVD as widely as possible, we published both Italian and English versions (Appendix 3).

In the following, we describe some aspects of the DVD. 


\subsection{QTVR image processing}

A preliminary but time-consuming step in preparing the QTVR navigation through the sites was processing the photographic material acquired in the field. Since light conditions were rather different during shooting campaigns, even in a day, the images have been corrected to obtain a uniform colour calibration, contrast and brightness.

The corrected images are then stitched together using a specific software, Apple QuickTime VR Authoring Studio ${ }^{\mathrm{TM}}$, to create a single QTVR panorama image that is the representation of a 3-D cylinder, virtually without any conical or spherical deformation (Figure 3).
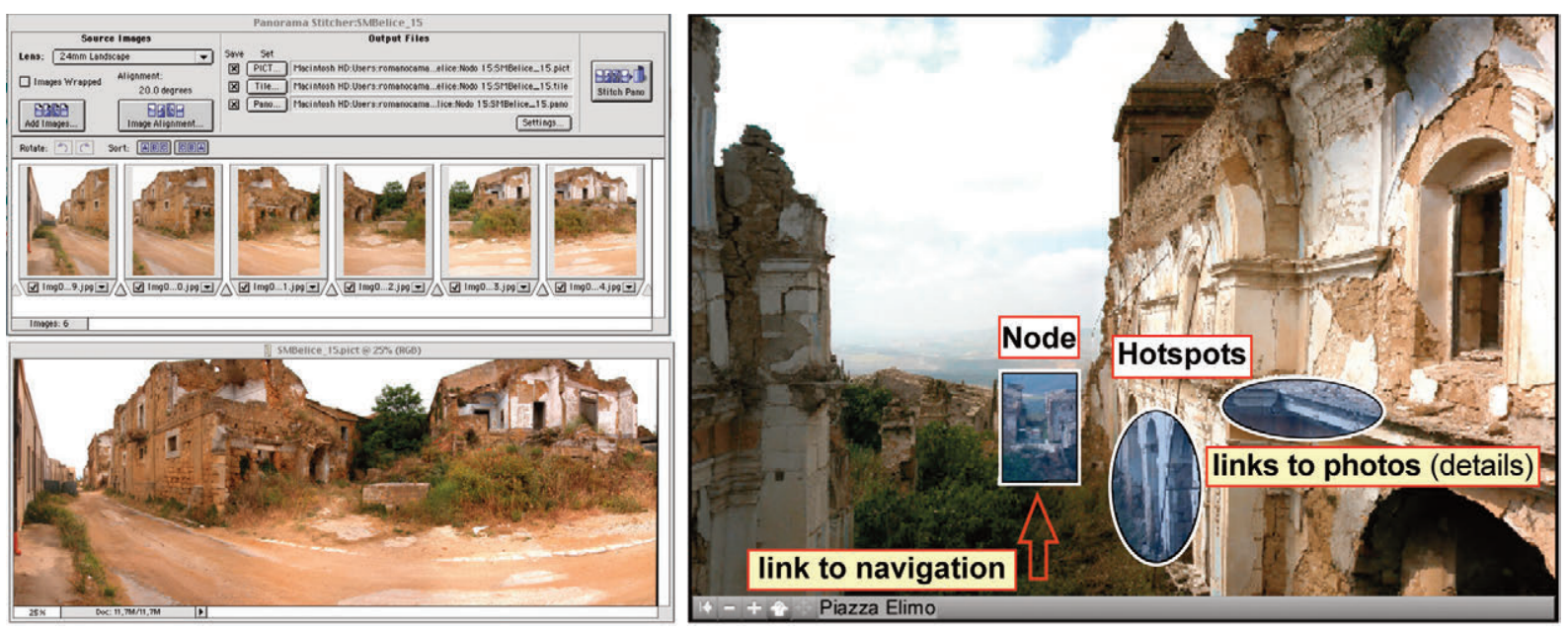

Figure 3. (left) Santa Margherita, example of stitching single images to obtain a QTVR panorama (single node); this panorama image is then converted into a movie by the QuickTime ${ }^{\mathrm{TM}}$ platform. (right) Poggioreale, example of QTVR window for interactive navigation throughout the nodes or static images showing details.

The next step was mounting the QTVR scenes, which represent a collection of more QTVR panoramas linked together via a set of hotspot areas. In the final QTVR scene, one for each settlement, the user can navigate from panorama to panorama (i.e. the nodes); each scene has an entry node showing the default view when the scene is opened, and it is enriched by links to static images to view architectonic details. The QTVR scenes are finally saved as a self-contained file in MOV format, which can be played by the QuickTime ${ }^{\mathrm{TM}}$ application compatible with both Macintosh and Windows platforms. For the case studies of Sicily, 146 nodes in all were mounted (Table 2).

\begin{tabular}{|c|c|c|c|c|c|c|}
\hline $\begin{array}{l}\text { Deserted } \\
\text { locality }\end{array}$ & Nodes $360^{\circ}$ & Nodes $270^{\circ}$ & Nodes $180^{\circ}$ & Total Nodes & Total shots & $\begin{array}{r}\text { Single } \\
\text { shots }\end{array}$ \\
\hline \multicolumn{7}{|l|}{ Val di Noto (1693) } \\
\hline Avola Vecchia & 2 & 1 & 1 & 4 & 60 & 42 \\
\hline Buscemi & 4 & 1 & 1 & 6 & 92 & 38 \\
\hline Calatabiano Vecchia & 3 & 3 & 1 & 7 & 113 & 68 \\
\hline Fenicia Moncada & 1 & & & 1 & 20 & 10 \\
\hline Licodia & 2 & & 1 & 3 & 46 & 6 \\
\hline Noto Antica & 4 & 3 & 7 & 14 & 178 & 78 \\
\hline Occhiolà & 10 & & & 10 & 186 & 26 \\
\hline Sortino Vecchia & 2 & & 2 & 4 & 58 & 68 \\
\hline Spaccaforno & 5 & 1 & 2 & 8 & 115 & 73 \\
\hline Terravecchia & 5 & & 1 & 6 & 103 & 33 \\
\hline
\end{tabular}


Raffaele Azzaro et al.

\begin{tabular}{|c|c|c|c|c|c|c|}
\hline $\begin{array}{l}\text { Deserted } \\
\text { locality }\end{array}$ & Nodes $360^{\circ}$ & Nodes $270^{\circ}$ & Nodes $180^{\circ}$ & Total Nodes & Total shots & $\begin{array}{l}\text { Single } \\
\text { shots }\end{array}$ \\
\hline \multicolumn{7}{|c|}{ Valle del Belìce (1968) } \\
\hline Gibellina & 6 & 1 & 1 & 8 & 144 & 30 \\
\hline Montevago & 7 & 2 & 2 & 11 & 183 & 44 \\
\hline Poggioreale & 11 & 4 & 8 & 23 & 289 & 150 \\
\hline Salaparuta & 8 & 1 & 1 & 10 & 184 & 80 \\
\hline Santa Margherita & 6 & 2 & 9 & 17 & 205 & 80 \\
\hline Santa Maria del Bosco & 3 & & 1 & 4 & 64 & 76 \\
\hline \multicolumn{7}{|l|}{ Val Dèmone (1783) } \\
\hline Gioiosa Guardia & 5 & 2 & 3 & 10 & 167 & 40 \\
\hline Total & 84 & 21 & 41 & 146 & 2207 & 942 \\
\hline
\end{tabular}

Table 1. Inventory of QTVR panoramas and single images used for the virtual navigation. File size of the nodes ranges from 3.5 to $34 \mathrm{Mb}$ each. The position of the single nodes for each abandoned settlement, is reported in Appendix 2.

\subsection{Structure of DVD and navigation}

Navigation is possible through three thematic paths: (i) Time, memory retrieved thanks to historical documents, (ii) Space, the land seen through pictures, (iii) Seismicity, natural causes and their features. Each path presents and links together the DVD contents from a different perspective, highlighting particular features.

In the section Time, we proposed seven movies that narrate brief stories focused on different moments of life with respect to the earthquake event, namely: The house, stables and hoe; Earthquake; Thinking about the living; 20 years in a shanty; Gibellina, museum-city; Poggioreale, old village nostalgia; Noto Antica, where time has stopped.

In the section Space, the virtual journey starts by choosing one of the three macro-areas studied (Figure 4). For each of them, documents are organized in a standard format: historical cartography (city maps before the earthquake); pictures (paintings or photos of the settlements before/after the event), films (for the 1968 event, illustrating destruction and way of living), newspapers, testimonials and poetry (remembering the event).

At a next level, the user selects the site of interest for the virtual visit. The QTVR window is flanked by an interactive map of the site showing the location of the selected node with the viewing angle (Figure 5). Detailed documentation is available for each site, with a similar standard format as the one of the above level; the additional items are: historical background (features and evolution of the settlement); testimonials (personal experiences and reports during the shock); government measures (rescue organization and reconstruction policies); the area (features of the territory with respect to the seismic hazard).

\subsection{Seismological data}

Lastly, information on earthquakes causing the abandonment of the settlements, is reported in the Seismicity section. Considering the rich bibliography available on the 1693-1783-1968 earthquakes, as well as the technical literature dealing with seismic risk issues in Sicily, we had to simplify the geophysical contents in order to provide only the key elements, enabling the user to gain an awareness of the seismic history of their own territory and the areas most exposed to risk.

To this end, we organized the section into three sub-topics: (i) regional seismicity (where and how earthquakes occur) and earthquakes leading to the abandonment of settlements (intensity maps, seismograms, simulations) (Figure 6); 


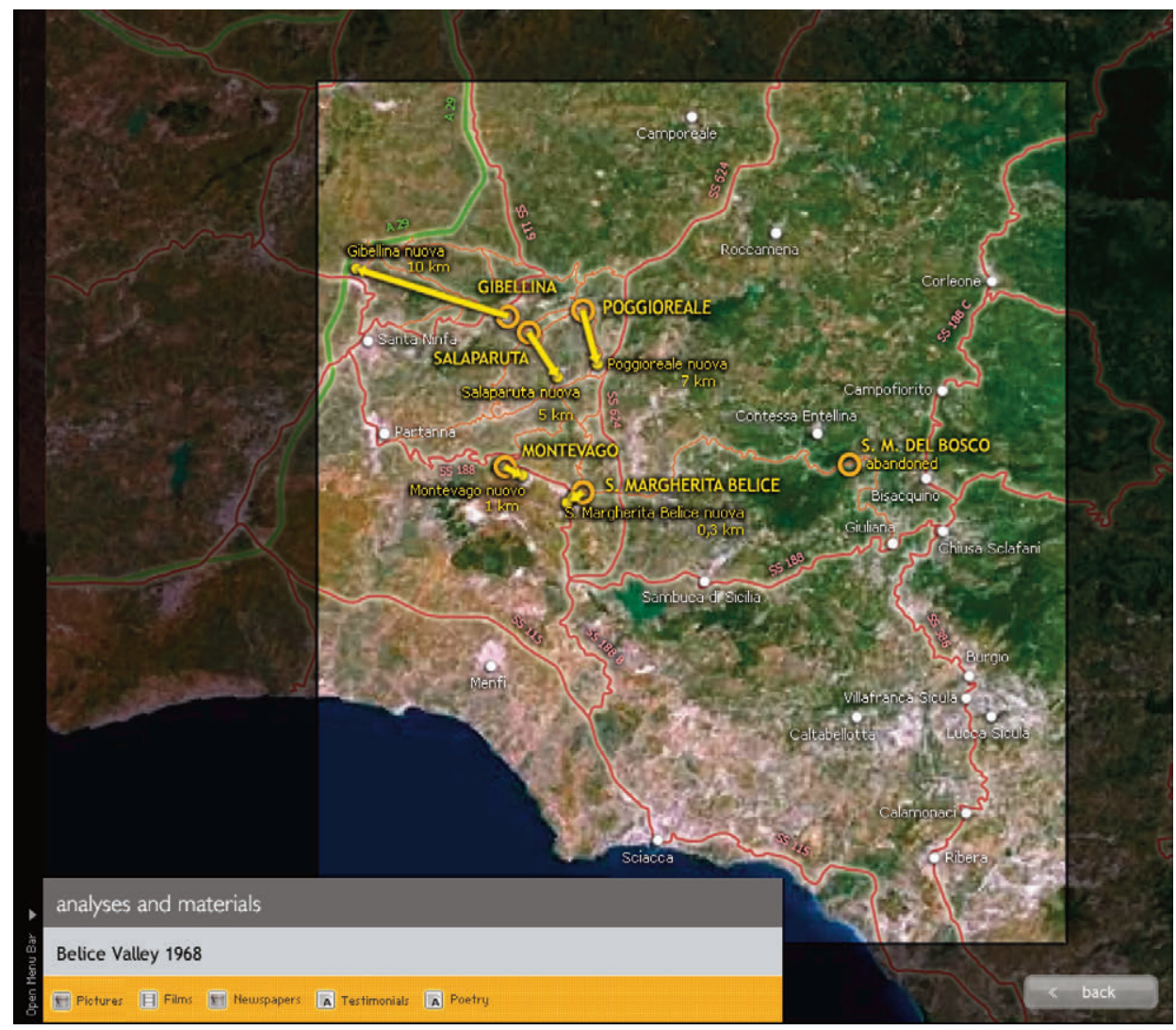

Figure 4. Access window to the Valle del Belice macro-area. When moving the mouse over the name of an abandoned locality, a yellow arrow shows the distance between the old and new settlement.

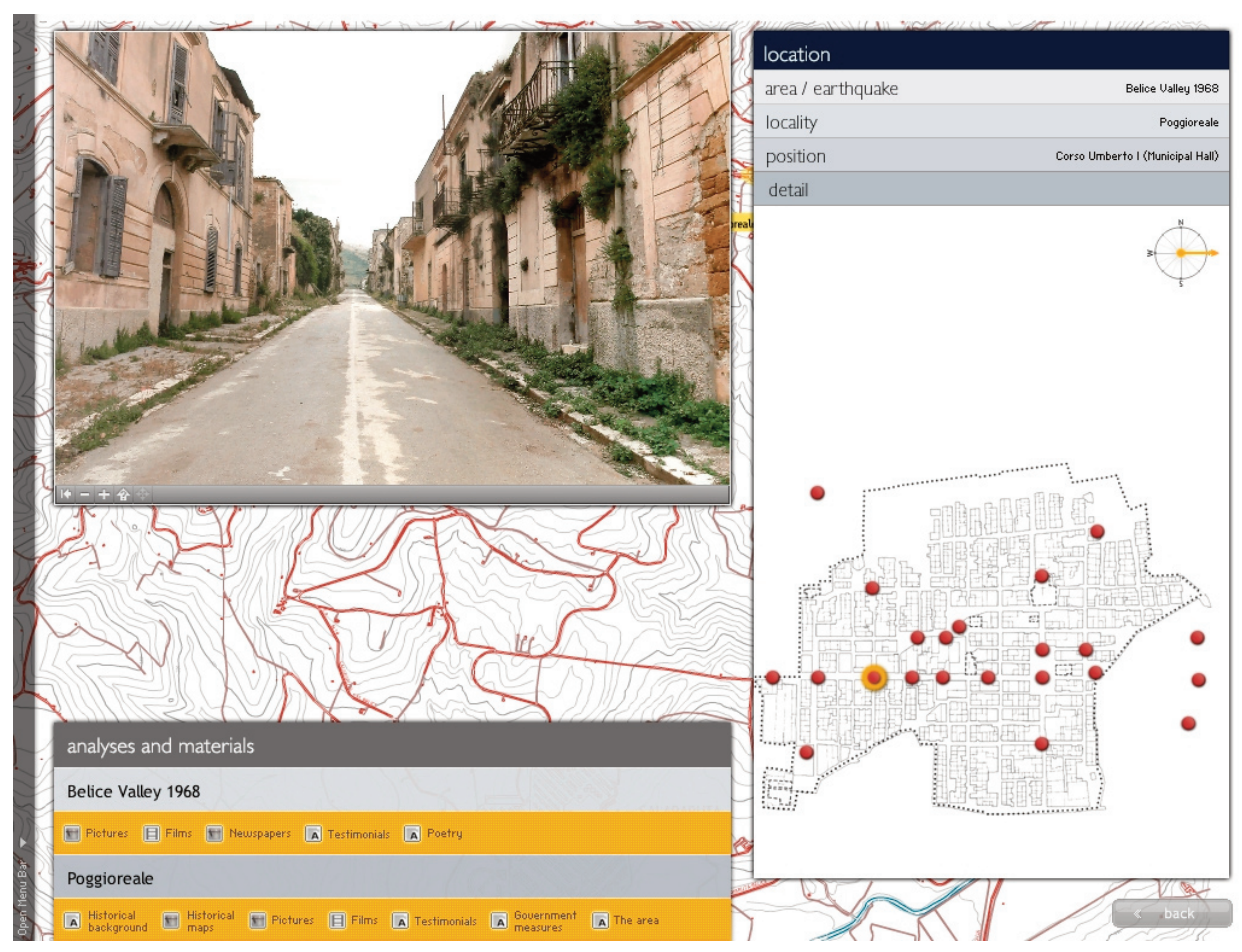

Figure 5. Virtual visit of Poggioreale and access to various features: exploring a site is possible using both the QTVR window (left) and the interactive topographic map (right); the selected node is highlighted in orange, and related information is also shown (on the top). 


\section{Raffaele Azzaro et al.}

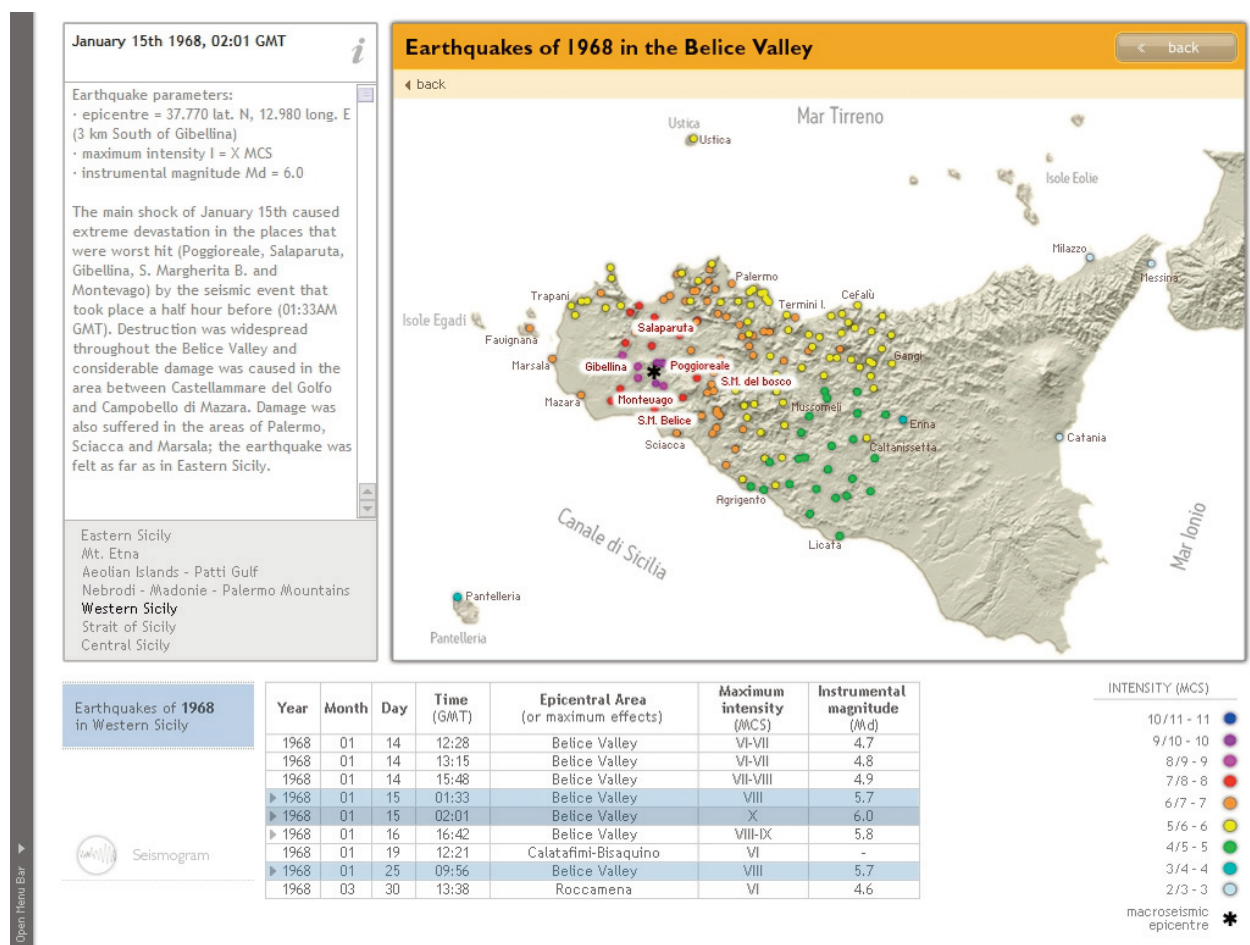

Figure 6. Screenshot of the 1968 seismic sequence. By moving the mouse over the map or clicking on the menu on the left the user can choose an area or an earthquake. The coloured lines on the table below provide a detailed macroseismic map for the specific event; the locations highlighted in red are links to the virtual visit.

(ii) maximum observed intensity and seismic history of any municipality in Sicily; (iii) seismic classification. Each of them is supported by interactive maps and relevant graphs, so users can select the place they live in.

\section{Ghost towns: a collective heritage to be preserved}

The archaeological traces of the abandoned settlements throughout Sicily appear today either as fairly substantial ruins or, for some recent cases, as half-destroyed villages. In the Val di Noto, the state of preservation of the sites is consistent with the lengthy period elapsed since 1693, overall field evidence being limited and, in a few cases, almost vanished. There is indeed a protection action by the Superintendence of the archaeological heritage, with the institution of zones subject to restrictions and, in the case of the most important sites (Noto Antica, Occhiolà, Terravecchia), there have been systematic excavations as well [Hofer, 1996; Barra Bagnasco, 2006; Racinet and Woimant, 2010]. But there is also the dramatic case of Fenicia Moncada, a site that in the last decades has been obliterated by an almost uncontrolled building development; today no more than a few stones remain, and people now living here unfortunately are not aware of the history of the old town (Figure 7).

On the other hand, the present condition of the ghost towns in the Valle del Belice is, in some ways, even more worrying, since they are quickly disappearing just 50 years after the event. Apart from Gibellina - which was initially almost completely destroyed by dynamite to prevent people remaining and later transformed into a plein air land art sculpture, the renowned Cretto - the other deserted settlements show very different degrees of conservation from each other. Salaparuta appears reduced to rubble, and only the convent of the Capuchins and the Holy Mother church were lately restored, but some architectonic details have been lost forever, also owing to thefts perpetrated over time (Figure 8).

At Montevago, preservation is limited to the establishment of a walking route throughout the centre and little else - the house of Baglio Ingoglia and a few watering troughs around the village - but the monumental Holy Mother church still appears as a heap of massive stones. Among the ghost towns of the Valle del Belìce, Santa Margherita undoubtedly represents the best example of recovering historical memory. Its symbolic places, the main square 

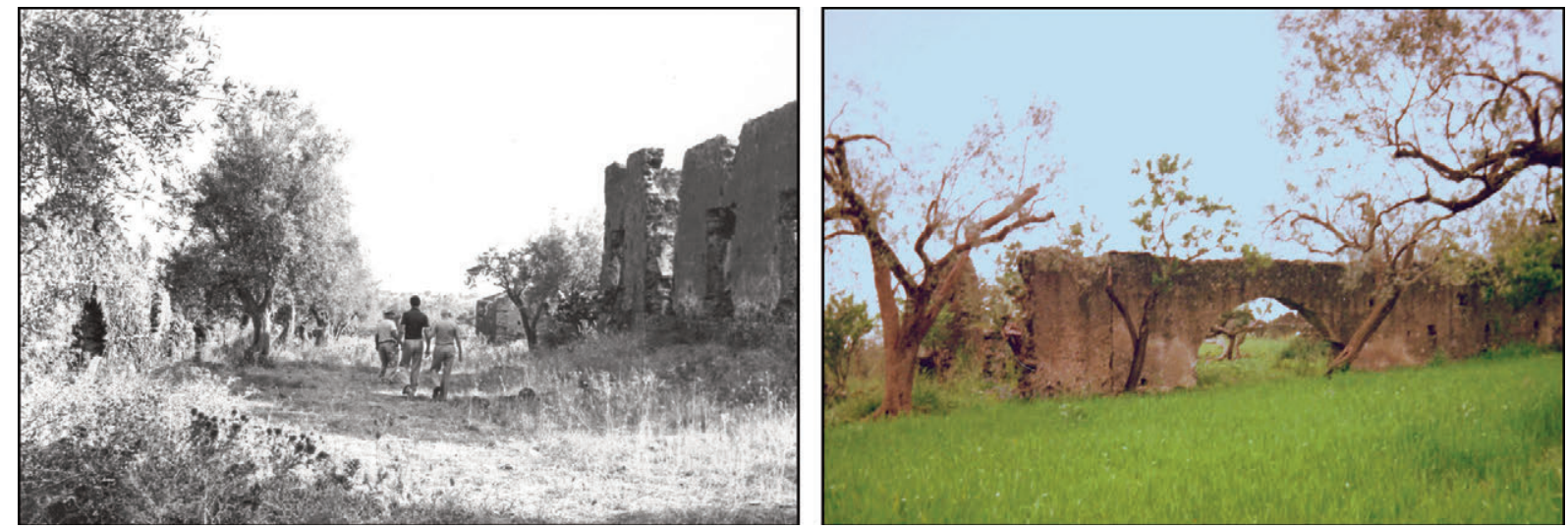

Figure 7. Fenicia Moncada, remains of old buildings in the 1970s. Today, everything has been destroyed by unregulated residential development and buildings.

with the Palace of the Princes Filangeri di Cutò (ancestors of Tomasi di Lampedusa, the author of The Leopard) and the remains of the Holy Mother church now integrated into the modern structure of the Museo della memoria, have been restored (Figure 9); some houses have also been repaired in the old, deserted part of the village.

Poggioreale survived the 1968 earthquakes to keep its urban layout almost intact - most buildings were still standing - and a visit to the village is really striking. In spite of this, no preservation action has been undertaken over the years so that it now represents the worst case of conservation of cultural heritage in the Valle del Belice.

Especially over the past decade, the entire structure of the village has been deteriorating rapidly; buildings have
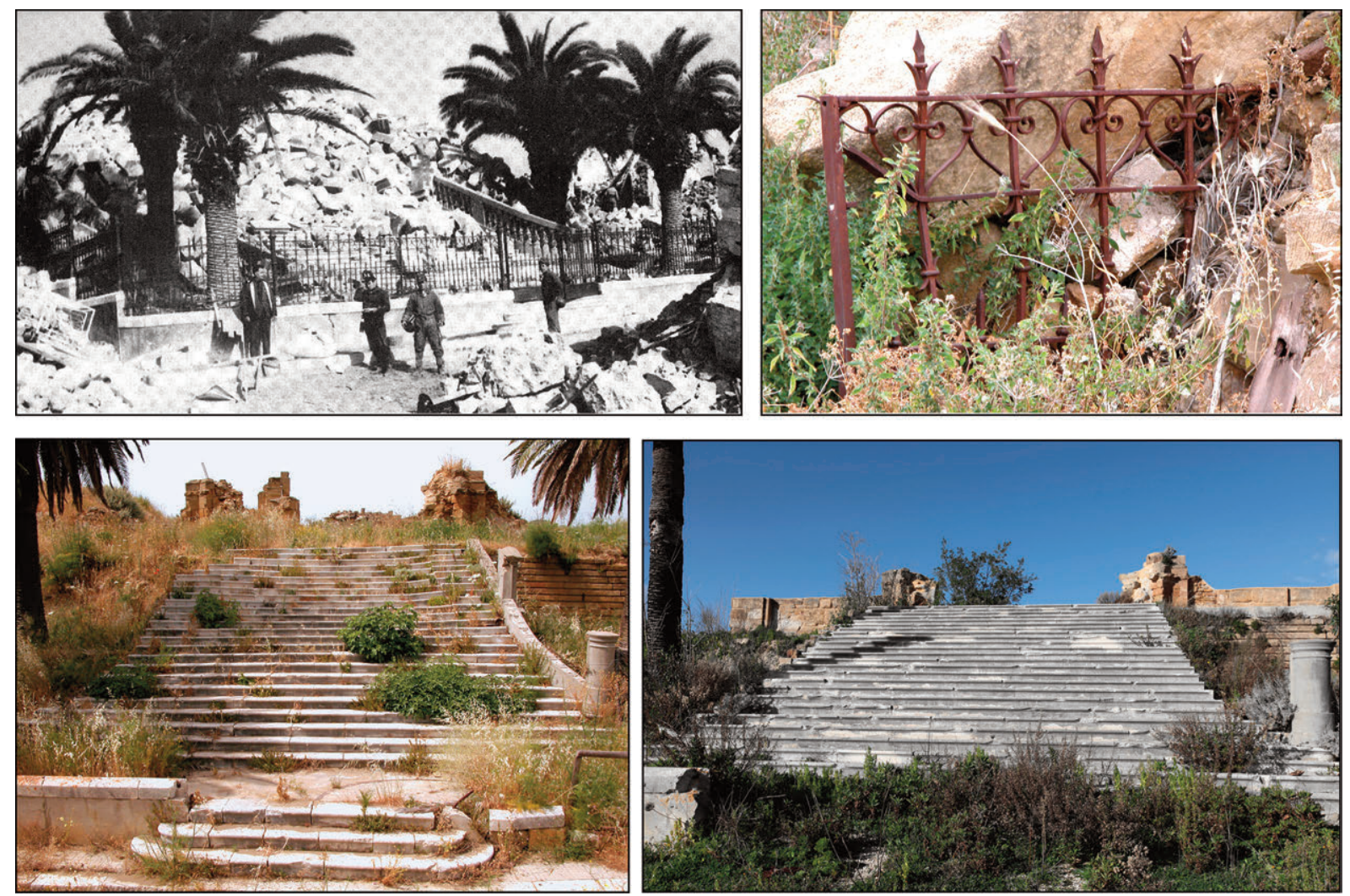

Figure 8. Salaparuta, degradation process of the Holy Mother church. Some architectonic details, such as the railings, balustrade and entrance steps are now definitively lost. 

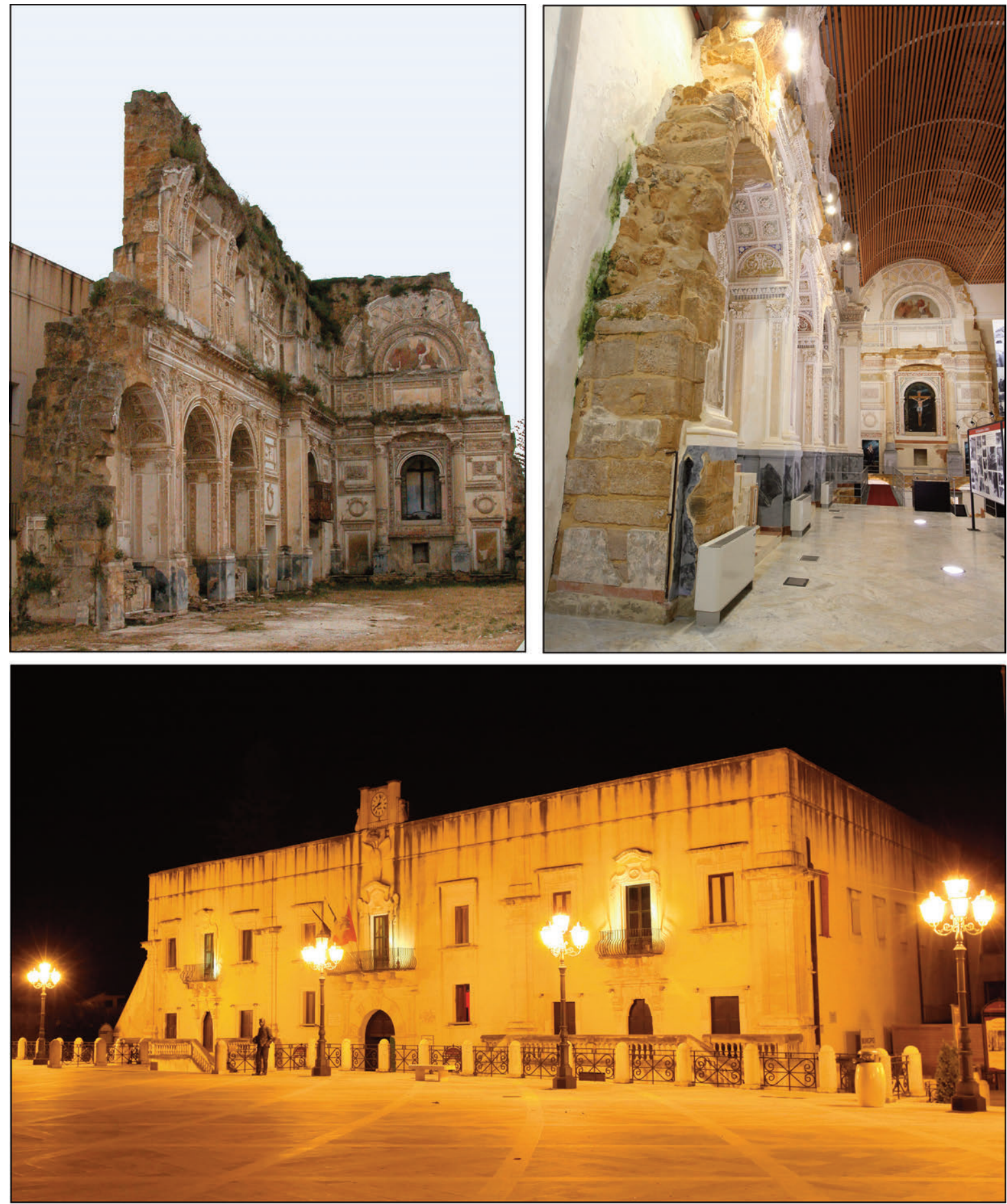

Figure 9. Santa Margherita, the symbolic places of memory: (top) the ruins of the Holy Mother church (left, in 2003) have been integrated within the structure of the Museo della memoria (right, in 2019), thus being preserved from deterioration due to weathering. (bottom) the Palace of the Princes Filangeri di Cutò, now a venue of the literary park dedicated to the writer Tomasi di Lampedusa.

collapsed and the remains having any architectonic relevance or significance for the local community are close to disappearing if urgent action is not undertaken (Figure 10). Moreover, in recent years the old settlement of Poggioreale is being used for international training of the Civil Protection, but this activity is having a negative impact on the conservation of the village due to the extreme fragility of the ruins.

Lastly, a similar misfortune struck the Benedictine abbey of Santa Maria del bosco, $15 \mathrm{~km}$ east of the other 

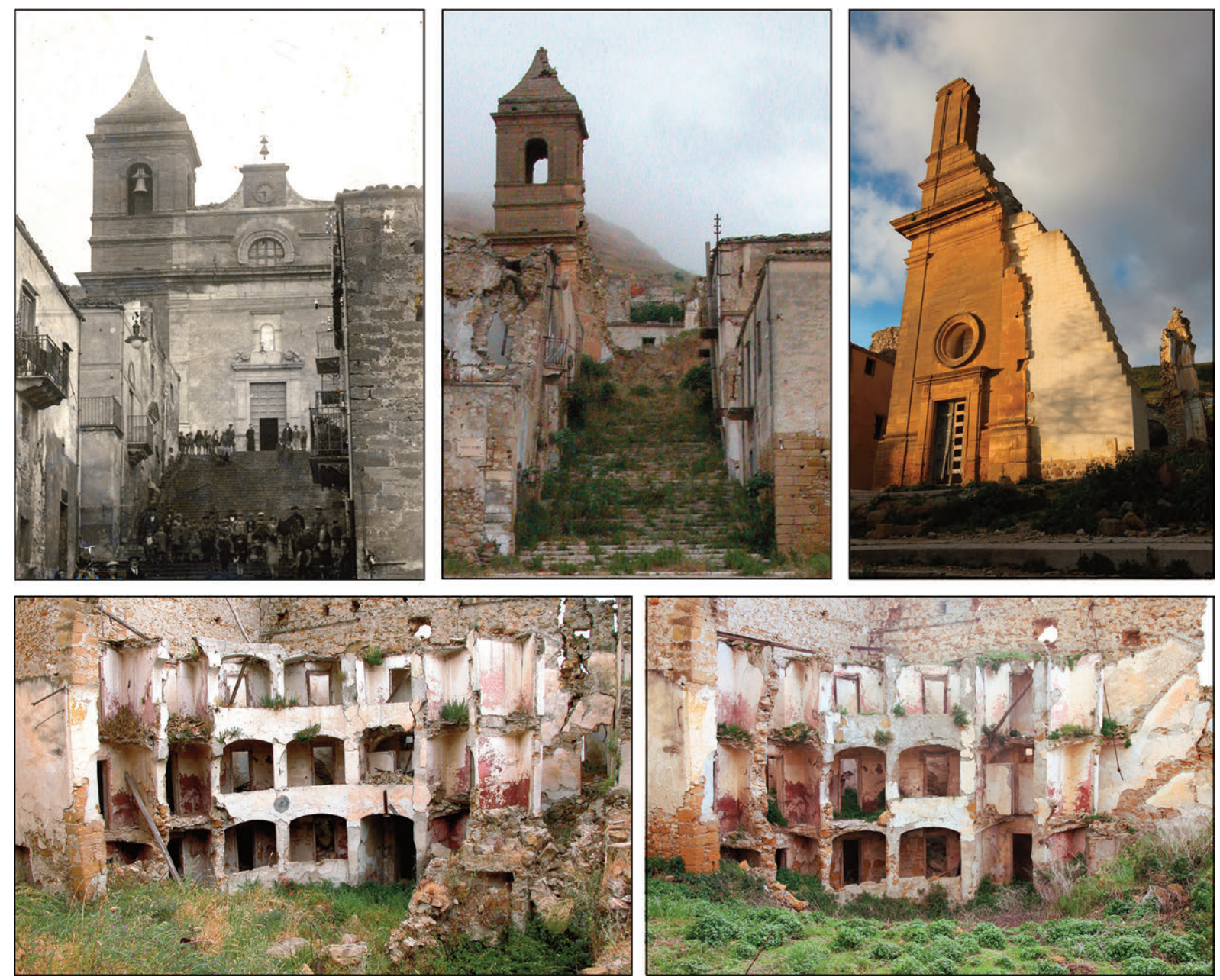

Figure 10. Poggioreale, the symbolic places disappearing: (top) the bell tower of the Holy Mother church in the early 1900s (courtesy of G. Coco), in 2003 and finally as it appears today, after the collapse occurring in 2009. (bottom) the degradation of the small theatre along the main street, is apparent in just 15 years.

abandoned settlements of the Valle del Belice. This place, little known to most people, is a magnificent pearl of great artistic and cultural value nestled in the woods of Mount Genuardo: the church contained majolicas by Luca della Robbia, while the monastery hosted the young Torquato Tasso before he wrote the poem Jerusalem Delivered. The monastery became privately owned after the unification of Italy in 1861; after the 1968 earthquakes, it was restored and more recently is being used as a resort. But, conversely, the monumental church is in a very bad condition since no conservation work has been undertaken: the building appears half- collapsed so that the interior is exposed to weathering processes, which are intense at an altitude of $800 \mathrm{~m} /$ asl (Figure 11).

\section{Conclusions}

The theme of the ghost towns is a complete educational and cultural tool to explore and interpret the traces left by destructive earthquakes in their own territory. This original methodological approach may be a key step in educational strategies to develop a real culture of preparedness and awareness on the issues of seismic risk; rediscovering abandoned settlements also provides a new perspective on the role of the cultural heritage and the significance of historical memory. A further aspect that should be mentioned is the importance of the abandoned towns for knowledge of the degradation process of the structures. This is a key issue in archaeoseismology, and these ruins offer the possibility of a systematic documentation of the degradation processes.

The process of abandoning and resettling a village, whether or not due to earthquakes or other causes, was rather 

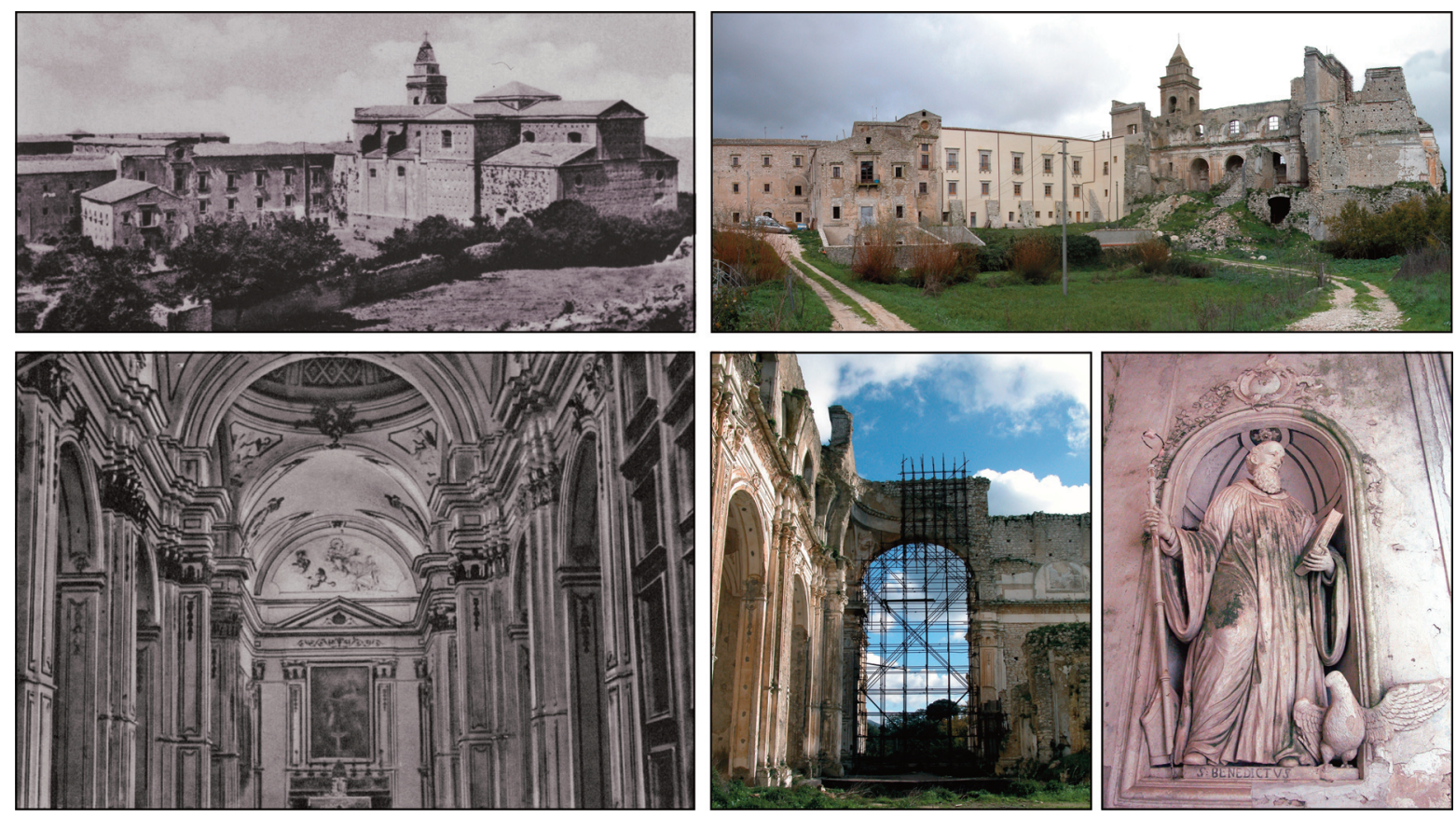

Figure 11. Santa Maria del bosco: (top) the abbey in the mid-1900s (courtesy of Mons. F. Ferina) and the present-day condition. Note the dramatic difference between the part of monastery entirely restored (privately owned, now it is a resort) while the church is collapsing. (bottom) the inner of the church in the mid-1900s, now the remains of apse, nave and ornaments are without any protection, exposed to very fast degradation processes.

frequent in Italy until the 1970s, with the 1968 Valle del Belice case-history probably representing the last most significant example. Thereafter, this choice was no longer proposed as a standard model for post-earthquake reconstruction, being limited to some extreme cases such as Friuli in 1976 and Irpinia in 1980 [Guidoboni and Valensise, 2011]. Following the 2017 Central Italy earthquakes, the debate today continues on whether the village of Pescara del Tronto should be reconstructed in the same place notwithstanding that the site is entirely located on a landslide (Rossi et al., 2019).

The lessons learned by the analysis of case-histories in Sicily highlight that the ghost towns are not adequately protected as a collective heritage, which deserves to be exploited and promoted in the framework of a network of outdoor museums. While the scars, moral and material, of the abandonment are still visible around the Valle del Belice, where the earthquake wreaked destruction fifty years ago, in the wealthy Val di Noto on the other hand, the seismic catastrophe of 1693 provided an opportunity for social and cultural rebirth, with the Sicilian Late Baroque as a unifying factor in the reconstruction [Dufour and Raymond, 1994]; the case-history of Noto is the most representative [Tobriner, 1982]. Now the area of south-eastern Sicily is in the UNESCO world heritage list (https://whc.unesco.org/en/list/1024), and continues to attract a huge number of visitors. However, in recent years there has been a new trend of academic, multi-disciplinary training throughout the areas struck by earthquakes in Italy, and also the ghost towns of the Valle del Belice are being rediscovered through a "naturalistic" walking journey that links history, anthropology and land planning (https://www.laboratoriodelcammino.com/sicilia-coast-to-coast).

Finally, the DVD devoted to the Sicilian ghost towns [Azzaro et al., 2006] represents a prototype multimedia tool whose methodological approach is still highly valid. Today, multimedia technology is more advanced and web-oriented, leading to the development of more dynamic on-line platforms, allowing introducing new towns and villages or materials. In this direction, for example, also the possibilities offered by the increasingly highresolution coverage by Google Street View could be applied to explore the ghost towns, to document the effects of current earthquakes [e.g. Hinzen, 2013] as well as to follow the changes in recent earthquake hit areas. Basing on new technology, the next stage of the virtual itineraries through the seismic history of Italy could be Calabria [Azzaro, 2012]. 
Acknowledgements. The authors are grateful to R. Camassi (INGV, Sezione di Bologna), who introduced us to the fascinating theme of the ghost towns in Italy and to the immersive QTVR navigation. We also wish to thank K.G. Hinzen and an anonymous referee for their useful comments, and express sincere gratitude to those for providing materials from their own personal collections: V. Belfiore (Noto), G. Bruno (Sortino), V. Bruno (Belpasso), M. Cardoni (Rome), G. Coco (Poggioreale), P. Magro (Avola), M. Rametta (Montevago), R. Taiani (Santa Margherita) and G. Zuccaro (Catania). Special thanks go to G. Tomarchio, who originally selected videos from the Italian television archives (now available on http://www.teche.rai.it/). Without all of these valuable contributions, the DVD would not have been really complete. Thanks to S. Conway for revising this text.

\section{References}

Azzaro, R., M. Cascone, R. Camassi, A. Amantia, F. Gugliemino, S. Mangiagli and L. Peruzza (2006). Earthquakes and ghost towns in Sicily: a journey through places of memory. INGV, Project Edurisk (Itineraries for the reduction of seismic risk), DVD-Rom, available also in Italian version.

Azzaro, R., C. Piccione and G. Valensise (2008). Terremoto Calabro Messinese, 1908/2008. Alinari-24 Ore, Firenze, 175, ISBN 978-88-6302-020-5.

Azzaro, R. (2012). Terremoti e città fantasma: un percorso attraverso le tracce degli eventi distruttivi del passato, Miscellanea INGV, 13, 24-28.

Barra Bagnasco, M. (2006). Da Terravecchia di Grammichele a Occhiolà. Archeologia di un insediamento della Sicilia centro orientale: campagne di scavo 2000-2001. Edizioni dell’Orso, Collana Mnème. Documenti, culture, storia del Mediterraneo e dell’Oriente Antico, 512, ISBN 978-88-7694-908-9

Bitelli, G., R. Camassi, M.A. Tini and L. Vittuari (2000a). From the photographic survey to the virtual reality movies and web integration for the study of an archaeological site, Proceedings of the 2nd international congress on "Science and technology for the safeguard of cultural heritage in the Mediterranean basin”, Paris, 5-9 July 1999, Elsevier, 1,149-151.

Bitelli, G., R. Camassi, M.A. Tini and L. Vittuari (2000b). Una realizzazione in realtà virtuale per la consultazione e l'esplorazione in remoto di un sito archeologico: la casa VIII in Bakchias. Papyrologica Lupiensia, 8, 91-101.

Branca, S., R. Azzaro, E. De Beni, D. Chester and A. Duncan (2015). Impacts of 1669 eruption and the 1693 earthquakes on the Etna Region, (Eastern Sicily, Italy): an example of recovery and response of a small area to extreme events. J. Volc. Geotherm. Res., 303, 25-40.

Camassi, R. (2004). I paesi abbandonati. Parametro, Rivista internazionale di architettura e urbanistica, 251,50-55.

Camassi, R., R. Azzaro, V. Castelli, F. La Longa, V. Pessina and L. Peruzza (2005). "Knowledge and practice”. Educational activities for reduction of earthquake impact: the EDURISK project, In: Proc. Int. Conf. on the 250th Anniversary of the 1755 Lisbon Earthquake, 1-4 November 2005, Lisbon (Portugal), 100-104.

Dufour, L. and H. Raymond (1994). 1693 Val di Noto: la rinascita dopo il disastro, Sanfilippo Ed., Catania, 316.

Gangemi, G. and R. La Franca (1979). Centri storici di Sicilia. Inventario di protezione dei sistemi urbani delle provincie di Trapani, Agrigento, Caltanissetta, Enna, Vittorietti Ed., Palermo, 1, 98.

Guidoboni, E. and G. Valensise (2011). Il peso economico e sociale dei disastri sismici in Italia negli ultimi 150 anni, 1861-2011. Bonomia University Press, Bologna, 550, ISBN 978-88-7395-683-9.

Hinzen, K. G. (2013). Support of macroseismic documentation by data from Google Street View. Seismological Research Letters, 84 (6), 982-990, doi:10.1785/0220130019.

Hofer, P. (1996). Idealstadt und Stadtraum im sizilianischen 18. Jahrhundert. GTA-Verlag, ETH Zurich, 171, ISBN 978-3-85676-049-6.

Kitchens, S. (1998). The QuickTime ${ }^{\mathrm{TM}}$ VR Book. Creating immersive imaging on your desktop, Peachpit Press, New York, 296., ISBN-13: 978-0201696844.

Klapisch-Zuber, C. (1973). Villaggi abbandonati e emigrazioni interne. Storia d'Italia, V, I documenti, 309-364.

Mollica, M. (2003). Gioiosa Marea. Dal Monte di Guardia a Ciappe di Tono e San Giorgio. A. Siciliano Ed., Messina, 303.

Pessina, V. and R. Camassi (2012). EDURISK 2002 - 2011: 10 anni di progetti di educazione al rischio, Miscellanea INGV, 13, 77.

Principe, I. (2001). Città nuove in Calabria nel tardo Settecento. Gangemi Editore, Roma, 410. 


\section{Raffaele Azzaro et al.}

Racinet, P. and G.P. Woimant (2010). Le site archéologique médiéval et moderne de Terravecchia (Sicile, Italie), Archéologie médiévale, 40, 49-88.

Rossi, A., A. Tertulliani, R. Azzaro, L. Graziani, A. Rovida, A. Maramai, V. Pessina, S. Hailemikael, G. Buffarini, F. Bernardini, R. Camassi, S. Del Mese, E. Ercolani, A. Fodarella, M. Locati, G. Martini, A. Paciello, S. Paolini, L. Arcoraci, C. Castellano, V. Verrubbi and M. Stucchi (2019). The 2016-2017 earthquake sequence in Central Italy: macroseismic survey and damage scenario through the EMS-98 intensity assessment. Bull. Earth. Eng., $17,2407-2431$.

Rovida, A., M. Locati, R. Camassi, B. Lolli and P. Gasperini (2016). CPTI15, the 2015 version of the Parametric Catalogue of Italian Earthquakes. INGV, http://doi.org/10.6092/INGV.IT-CPTI15. http://emidius.mi.ingv.it/CPTI15-DBMI15/.

Stern, J. and R. Lettieri (2002). QuickTime 6 for Macintosh and Windows. Visual quickstart guide, Peachpit Press, New York, $3^{\text {rd }}$ edition, 520, ISBN-13: 978-0321127280.

Teti, V. (2004). Il senso dei luoghi. Paesi abbandonati di Calabria. Ed. Donzelli, Roma, 569.

Tobriner, S. (1982). The genesis of Noto: an Eighteenth-Century Sicilian city. University of California Press, Studies in Architecture, 21, 252. 